\title{
IMPROVING THE PSYCHOMETRIC PROPERTIES OF THE MOONEY PROBLEM CHECKLIST BY USING RASCH MEASUREMENT MODEL
}

\author{
M. E. E. M. Matore ${ }^{1, *}$, A. Z. Khairani ${ }^{2}$, N. A. $\operatorname{Razak}^{2}$ and M. Mohamad ${ }^{1}$ \\ ${ }^{1}$ Faculty of Education, UniversitiKebangsaan Malaysia, 43600 Bangi, Selangor, Malaysia \\ ${ }^{2}$ School of Educational Studies, UniversitiSains Malaysia, 11800 Penang, Malaysia
}

Published online: 10 November 2017

\begin{abstract}
This study aims to examine the psychometric characteristics of Mooney Problem Checklist (MPCL) items using the Rasch measurement model framework in the context of polytechnics. The MPCL with eleven dimensions was administered to 252 respondents who were selected from seven polytechnic institutions in Malaysia. The analysis was conducted using WINSTEPS 3.71.0.1 in order to examine the psychometric properties such as item fit statistics, unidimensionality, local independence, item polarity, reliability, separation index and item-person map with reference to Rasch measurement model. The results obtained showed that 244 items from 327 items was found to have fulfilled the main assumptions and measurement criteria of Rasch measurement model. This study provides significant contribution to improving the scale development and validation of MPCL instrument modification using the Rasch measurement model in the context of polytechnics in Malaysia.
\end{abstract} Keywords: Mooney Problem Checklist; adversities; polytechnic; Raschmeasurement model.

Author Correspondence, e-mail: effendi@ukm.edu.my

doi: http://dx.doi.org/10.4314/jfas.v9i6s.32 


\section{INTRODUCTION}

\subsection{Mooney Problem Checklists (MPCL)}

The Mooney Problem Checklist (MPCL) was developed by Ross L. Mooney and Leonard V. Gordon in 1950. The MPCL was developed by Mooney in 1950 to empirically synthesize's problems encountered by young people's more systematically[1]. The MPCL consists of 330 items and covered 11 dimensions of problems namely (a) health, (b) finance, (c) recreation, (d) courtship, (e) social, (f) personal, (g) religion, (h) family, (i) career, (j) education and (k) learning. The MPCL is considered one of the most useful instruments to categorize many categories of 11 dimensional of problemsas well as providing opportunity for respondents to list their new problems. TheMPCL is popular in Malaysia because it is easily administered, does not require in-depth knowledge and the respondents are also given an opportunity to list their opinion or view on new problem that they might faced[2]. Previous researchers also using MPCL for finding the adversities among students such as study by[3-5].

However, we cannot ignore the influence of culture in a study especially when using instrument/questionnaire developed from other culture. For example, the problems faced by each individual from various countries, institutions, and levels of schooling are not the same. In addition, the MPCL was developed almost 65 years ago, and its suitability as well as its psychometric properties can be questionable. The cultural context and time are believed to have an influence on response given by the respondents on particular item. One might speculate that there is a probability that some items might be no longer relevant. As such, it is timely to evaluate the adequacy of MPCL items within the context of Malaysian respondents which has never been conducted. Previous studies dealt only with reliability analysis [6-7] or descriptive statistics in terms of mean, standard deviation and percentage [7-10]. This paper intends to fill the gaps from the previous research by examining both item-level and ability-level statistics of the MPCL. The purpose of this study is to determine the best items to measure the adversities among students and demonstrate good psychometric properties evidence at the test level guided by the Rasch Measurement Model.

The objective of the study is to examine the psychometric characteristics of items in Mooney Problem Checklist (MPCL) using the Rasch measurement model such as item fit statistics, unidimensionality, local independence, item polarity, reliability, separation index and 
item-person map in the context of polytechnics.

\section{LITERATURE REVIEW}

\subsection{Previous study}

Many studies have been conducted using MPCL to identify the problems faced by students in different settings such as those among international students [11], Muslim adolescent students [8], secondary school students [7] and university students [12]. The types of problems include social and recreational, curriculum and method of teaching, educational guidance, adaptation and career.

\subsection{Rasch Measurement Model}

The Rasch Measurement Model (RMM) helps explains the response on observable traits to estimate unobservable traits of a particular construct. RMM involves modeling two important parameters in testing namely, (1) item difficulty (observable trait) and (2) respondents' ability (unobservable trait). The relationship between the two parameters is given as the following equation:

$P_{i}=\frac{\exp \left(\beta_{n}-\delta_{i}\right)}{1+\exp \left(\beta_{n}-\delta_{i}\right)}(1)$

where $\mathrm{P}_{\mathrm{i}}=$ probability of getting a correct answer for Item I, $\beta_{\mathrm{n}}=$ ability parameter for respondent $\mathrm{n}$ and $\delta_{\mathrm{I}}=$ difficulty parameter of an item $\mathrm{I}$.

Rasch measurement analysis provides various statistics to examine the quality of the items and test such as item fit, unidimensionality, local independence, item polarity, reliability index, separation index and item person map. For item fit evaluation, the suitable item is calculated by the mean-square residual fit statistics. This statistics indicates whether the items fit to the model [13]. Rasch analysis produces both Infit and Outfit Mean Square (MNSQ) in determining the fit of persons and items to the construct [14].The Infit and Outfit Mean Square (MNSQ) values range from 0.77 logits to 1.30 logits was taken as a cut off values to evaluate the item fit[15]. Items outside of these range values of MNSQ are considered to be overfitted or misfitted. Overfit means the items are too predictive while misfit means the items are too erratic [16]. These items can be excluded in subsequent analyses.

The unidimensionality indicates the detection of construct validity in the tests that have been 
developed. The test item should validateaccording toRasch model to confirm the construct validity [17]. The dimensionality of a scale is examined using the Rasch Principal Components Analysis (PCA) in order to ascertain the unidimensionality of MPCL. If this assumption is met, then the Rasch model can be used to test the psychometric features of an instrument.Another assumption that must be fulfilled when examining the psychometric properties of the items is local independency. Local independence is proven when the Rasch measures explain all systematic differences among the data so that there is independence among the residual differences between the observed data and those expected from the Rasch measures. Lack of local independencejust like other forms of misfit degrades the measurement process and increases standard errors [18]. The item polarity is a statistic that proved that all items work together to define a single construct of measurement [19].The item polarity should show a positive value [16,20] of more than 0.3 [21]. A high value of PTMEA Corr. will show the ability of the items to differentiate between the ability of the respondents [22].

Instead of the statistics discussed previously, the quality of measurements made using the Rasch model can be demonstrated by using four statistics: (a) person reliability (to determine the consistency of person responses), (b) person separation (to estimate the ability of the instrument to separate participants into different levels of the construct), (c) item reliability (to estimate how well the items cohere) and (d) item separation (to estimate the ability of the participants to distinguish between items measuring different levels of the construct) [23]. The item person map will show a hierarchy of person ability and item difficulty in a straight line. The map will provide a visual representation of the person and item on the construct. The Wright map showed the distribution of the person and items on the logit measurement ruler, making it simpler to visualize the persons' ability and difficulty of tasks [24].

\section{METHODOLOGY}

\subsection{Research Design}

This study employed a quantitative research approach and survey technique using a questionnaire developed by Mooney and Gordon (1950) to collect data from the identified sample for the study. 


\subsection{Sample Selection}

Table 1 shows the responses from each categories namely gender, name of polytechnic, semester of study and department. A total number of 252 students was purposively selected from eight different department in seven polys situated in five different zones namely north, west, east, south (Peninsular Malaysia) and Sabah and Sarawak (East Malaysia).Purposive sampling was employed due to the need for selecting a sample which is voluntarily to participate, could give good cooperation, and easily accessed [25]. This technique of purposive sampling could guide to develop a more in-depth study on a phenomena that exist in a population [26]. It means that the researchers can obtain more information about the advertisites that they had in polytechnics. 
Table 1. Profile of respondents

\begin{tabular}{|c|c|c|c|}
\hline Category & Sub Category & Frequency & Percentage \\
\hline \multirow[t]{2}{*}{ Gender } & Male & 126 & $50.0 \%$ \\
\hline & Female & 126 & $50.0 \%$ \\
\hline \multirow[t]{7}{*}{ Polytechnic } & Polytechnic-Borneo Zone & 50 & $19.8 \%$ \\
\hline & Premier Polytechnic-South Zone & 40 & $15.9 \%$ \\
\hline & Polytechnic-North Zone & 40 & $15.9 \%$ \\
\hline & Polytechnic-East Zone & 40 & $15.9 \%$ \\
\hline & Polytechnic A-South Zone & 40 & $15.9 \%$ \\
\hline & Metro Polytechnic-West Zone & 24 & $9.5 \%$ \\
\hline & Polytechnic B-South Zone & 18 & $7.1 \%$ \\
\hline $\begin{array}{l}\text { Year of } \\
\text { study }\end{array}$ & First semester & 56 & $22.2 \%$ \\
\hline \multirow[t]{4}{*}{ (semester) } & Second semester & 56 & $22.2 \%$ \\
\hline & Third semester & 52 & $20.6 \%$ \\
\hline & Fifth semester & 44 & $17.5 \%$ \\
\hline & Sixth semester & 44 & $17.5 \%$ \\
\hline Type of & Commerce Department (JP) & 62 & $24.6 \%$ \\
\hline \multirow[t]{8}{*}{ programme } & Electrical Engineering Department (JKE) & 50 & $19.8 \%$ \\
\hline & Mechanical Engineering Department (JKM) & 44 & $17.5 \%$ \\
\hline & Hospitality Department (JH) & 32 & $12.7 \%$ \\
\hline & Civil Engineering Department (JKA) & 30 & $11.9 \%$ \\
\hline & $\begin{array}{c}\text { Information Technology and Communication } \\
\text { Department (JTMK) }\end{array}$ & 20 & $7.9 \%$ \\
\hline & Visual and Computer Design Department (JRKV) & 10 & $4.0 \%$ \\
\hline & $\begin{array}{l}\text { BioIndustry and Agrotechnology Department } \\
\qquad(\mathrm{JAB})\end{array}$ & 4 & $1.6 \%$ \\
\hline & & 252 & $100 \%$ \\
\hline
\end{tabular}




\subsection{Instrument Administration}

This study used the MPCL to collect data from the sample of polytechnic students on the challenges the face during their study in the polytechnic. The concept of the challenges in this study refers to the problems faced by polytechnic students with reference to the dimensions of MPCL as conceptualized by [1]. The MPCL comprised eleven dimensions as shown in Table 2. However, three items from the dimension of friendship have been removed from the original instrument because it is considered inappropriate to the Malaysian context. The MPCL in Malay Language was adapted from a previous study conducted by [27] from the Faculty of Education, University of Malaya.

Table 2. MPCL items according to the dimensions

\begin{tabular}{clc}
\hline No. & \multicolumn{1}{c}{ Dimensions } & Item No. \\
\hline 1 & Health (health and physical development) & $01-30$ \\
2 & Finance (finance, living conditions and employment) & $31-60$ \\
3 & Recreation (social and recreational activities) & $61-90$ \\
4 & Courtship (courtship, sex and marriage) & $91-117$ \\
5 & Social (social - psychological relations) & $118-147$ \\
6 & Personal (personal - psychological relations) & $148-177$ \\
7 & Religion (morals and religion) & $178-207$ \\
8 & Family (home and family) & $208-237$ \\
9 & Career (future - vocational and educational) & $238-267$ \\
10 & Education (adjustment to school work) & $268-297$ \\
11 & Learning (curriculum and teaching procedures) & $298-327$ \\
\hline
\end{tabular}

In this research context, the responses of all items were measured using Likert scale whereby the original scale was changed to three Likert point scale namely Not Interfere at all (0), Not so Interfere (1) and Very Interfere (2). MPCL is not intended to produce scores to make inferences, but it was intended to detect the type of the main problems [1].

\subsection{Research Procedures}

The permission to conduct the study was obtained from the Centre for Research and Innovation and the Director for each polytechnic. Permission is also obtained from the Student Affairs Officer within each polytechnic institution, especially to gather the student data for the 
selection of the sample. The distribution of the instruments and the briefing were conducted face to face with the students. The test was administered within one hour, with the cooperation from the lecturer of the polytechnic institution. All students successfully completed the instrument. Students were given about one hour to answer all items completely.

\subsection{Data Analysis}

The students' response was entered into SPSS version 19.0 and analyzed using WINSTEPS version 3.71.0.1 in order to examine the psychometric properties of the items and test. The analysis produced several statistics that can be used to examine the quality of the items such as item and person reliability, item and separation index, INFIT and OUTFIT MNSQ for item fit and RPCA analysis for unidimensionality and local independence. In addition, other analyses were performed to examine item polarity and DIF.

\section{RESULTS AND DISCUSSION}

This study considers two assumptions of the Rasch model for the selection of items such as item fit, unidimensionality, local independence, item polarity, reliability index, separation index, and item-person map.

\subsection{Item Fit}

Table 3 shows the examples of several items that have been accepted based on item fit statistics and polarity items for eleven dimensions of MPCL. This study used both infit and outfit MNSQ in order to examine the model items fitness. The suitability of an item in measuring the construct was informed by the fit statistics [28]. The standard error (SE) for each item is found in ranges from 0.11 to 0.09 and can be considered as excellent [15]. The standard error is significant in establishing the precision in estimation [29]. The item polarity showed positive value of more than 0.3 [16]. These qualities demonstrated that all things get together to characterize a unidimensional develop of estimation. 
Table 3. Examples of items accepted

\begin{tabular}{|c|c|c|c|}
\hline Entry Number & MNSQInfit & MNSQ Outfit & Dimensions \\
\hline 6 & 1.10 & 1.20 & Health \\
\hline 11 & 0.99 & 1.16 & Health \\
\hline 15 & 1.03 & 1.20 & Health \\
\hline 19 & 1.08 & 1.18 & Health \\
\hline 32 & 1.07 & 1.19 & Finance \\
\hline 38 & 1.05 & 1.16 & Finance \\
\hline 48 & 1.15 & 1.10 & Finance \\
\hline 49 & 1.03 & 1.04 & Finance \\
\hline 62 & 0.98 & 1.20 & Recreation \\
\hline 63 & 1.12 & 1.22 & Recreation \\
\hline 65 & 0.94 & 1.06 & Recreation \\
\hline 66 & 1.07 & 1.23 & Recreation \\
\hline 91 & 1.13 & 1.13 & Courtship \\
\hline 92 & 1.12 & 1.17 & Courtship \\
\hline 93 & 1.09 & 1.07 & Courtship \\
\hline 94 & 1.05 & 0.99 & Courtship \\
\hline 118 & 1.01 & 1.10 & Social \\
\hline 119 & 1.05 & 1.12 & Social \\
\hline 121 & 0.96 & 1.01 & Social \\
\hline 122 & 1.25 & 1.23 & Social \\
\hline 148 & 1.11 & 1.21 & Personal \\
\hline 149 & 0.99 & 1.04 & Personal \\
\hline 150 & 0.96 & 0.96 & Personal \\
\hline 152 & 0.88 & 0.89 & Personal \\
\hline 180 & 1.15 & 1.07 & Religion \\
\hline 181 & 1.03 & 1.02 & Religion \\
\hline 182 & 1.02 & 1.02 & Religion \\
\hline
\end{tabular}




\begin{tabular}{llll}
183 & 1.18 & 1.10 & Religion \\
208 & 1.09 & 1.16 & Family \\
209 & 1.17 & 1.19 & Family \\
210 & 1.12 & 1.24 & Family \\
211 & 0.92 & 0.84 & Family \\
238 & 1.03 & 1.11 & Career \\
239 & 0.84 & 0.86 & Career \\
240 & 0.94 & 0.98 & Career \\
241 & 0.90 & 0.90 & Career \\
268 & 1.00 & 0.97 & Education \\
269 & 0.97 & 0.93 & Education \\
270 & 0.88 & 0.82 & Education \\
271 & 0.89 & 0.84 & Education \\
298 & 0.92 & 0.92 & Learning \\
299 & 0.92 & 0.89 & Learning \\
300 & 0.91 & 0.88 & Learning \\
301 & 0.94 & 0.91 & \\
\hline & & & \\
\hline
\end{tabular}

\subsection{Unidimensionality}

In this study, unidimensionality is examined using the Rasch Principal Components Analysis (PCA). The PCA discoveries demonstrated that raw variance as clarified by measure is $26.6 \%$ for fulfilling the dimensionality requirements of the scale by at least $20 \%$ [30]. The level of noise is $4.2 \%$, which is less than $10 \%$ according to the evidence to infer the unidimensionality of the scale [15, 31-32]. In addition, the ratio of raw variance is $4: 1$ and acceptable [33].

\subsection{Local Independence}

Ten items are found to have standard relationship of remaining values within the range between 0.67 to 0.78 . These values fulfill the local independence needs which mentioned thatthe correlation values suggested to be belowthan 0.80 [34]. It proves that the residuals stacked in inverse bearings on the first scale [35]. Table 4 shows the standard correlation of residual values. The data showed that these items might demonstrate a matter of similarity or 
could be misleading.

Table 4. The correlation of residuals

\begin{tabular}{ccccc}
\hline Correlation & Items & Dimension & Items & Dimension \\
\hline 0.78 & Q220 & Family & Q221 & Family \\
0.76 & Q248 & Career & Q249 & Career \\
0.74 & Q243 & Career & Q244 & Career \\
0.74 & Q254 & Career & Q255 & Career \\
0.73 & Q256 & Career & Q257 & Career \\
0.72 & Q118 & Social & Q119 & Social \\
0.70 & Q249 & Career & Q250 & Career \\
0.69 & Q314 & Learning & Q315 & Learning \\
0.67 & Q250 & Career & Q251 & Career \\
0.67 & Q154 & Personal & Q155 & Personal \\
\hline
\end{tabular}

There are two approaches that can be taken on these items: either (a) the item should be maintained by changing the sentence structure of the items and making it clearer, or (b) the item needs to be dropped based on the item fit analysis for each item [36]. Subsequent study can be conducted by changing the structure of the items. The researcher can also build more items of the MPCL with high accuracy to test further dimensions among the respondents.

\subsection{Reliability and Separation Index}

Overall, the person reliability index estimated high, which is 0.99 and the items reliability index is 0.90. The Cronbach Alpha recorded of 0.99 and exceeding the cut-off value of 0.8 $[16,37]$. For the MPCL dimensions, the reliability coefficient of the person ranges from 0.70 to 0.92 and the item reliability ranges from 0.78 to 0.93 . The reliability coefficient exceeded the acceptable value of 0.70 [38] which indicates the internal consistency of the scale. Table 5 showed the item reliability for 11 MPCL dimensions. 
Table 5. The reliability and separation index

\begin{tabular}{lcccc}
\hline \multirow{2}{*}{ Dimensions of MPCL } & \multicolumn{2}{c}{ Reliability Index } & \multicolumn{2}{c}{ Separation Index } \\
& Person & Item & Person & Item \\
\hline Health & 0.82 & 0.93 & 2.10 & 3.79 \\
Finances & 0.70 & 0.89 & 1.51 & 2.88 \\
Recreation & 0.84 & 0.88 & 2.30 & 2.72 \\
Courtship & 0.85 & 0.91 & 2.40 & 3.10 \\
Social & 0.90 & 0.78 & 3.03 & 1.86 \\
Personal & 0.91 & 0.88 & 3.17 & 2.66 \\
Religion & 0.89 & 0.91 & 2.90 & 3.20 \\
Family & 0.91 & 0.85 & 3.22 & 2.42 \\
Career & 0.90 & 0.90 & 2.97 & 3.07 \\
Education & 0.91 & 0.89 & 3.23 & 2.91 \\
Learning & 0.92 & 0.86 & 3.50 & 2.47 \\
& 0.99 & 0.90 & 8.19 & 3.03 \\
\hline
\end{tabular}

For individual reliability, the items can distinguish between one individual to another for a given measured variable $[16,28]$. The items' reliability indicates the possibility to obtain those items at similar locations throughout the scale, even though the same items are given to another individual sample with the same level of ability [16].

Person separation index for the main scale (MPCL) was recorded at a value of 8.19 , and the items separation index was 3.03. The separation index in the ranges of three to four is considered good and that exceeding five is considered to be excellent [15]. Thus, the findings indicate that the person separation index is excellent and the items' separation index is good. Based on each dimension, the separation index of an item ranges from 1.86 to 3.79 . Meanwhile, the separation index of a person ranges from 1.51 to 3.50. Even though these figures of a minimum value of 1.51 and 1.86 can be rounded to 2.00 , these values can still be acceptable [39]. In fact, the findings are also in line with the suggestion that, for an instrument to be useful, separation should exceed 1.0 with higher values of separation representing a greater spread of items and persons along a continuum [40]. The findings indicates that the distribution of items along the scale can separate individuals according to their abilities and 
based on item difficulty [28]. The separation and number of strata of items for all MPCL dimensions indicates that the items in the test are distributed fairly with individual abilities in logits (log odd units) [16]. Based on the overall analysis, a total of nine strata abilities are identified in the sample whereas the items' separation index shows that there are three strata of the items' difficulty item (easy, medium and hard). It means that how difficult the items based on the respondents.

\subsection{Item-Person Map}

The Wright map illustrates the distribution of the person and items on the logits measurement ruler, which make it easier to visualize the distribution of a person's ability and item difficulty of the tasks. Item maps were produced as part of the item fit analysis to provide a visual representation of person and item locations on the construct. Persons are located along the linear scale based on the level of adversity (i.e., the amount of construct present in individual respondents) while items are located based on their endorsement difficulty level (i.e., degree of difficulty of answering such as $(0=$ Not Interfering at all $),(1=$ Not so Interfering $)$ and $(2=$ Very Interfering). 


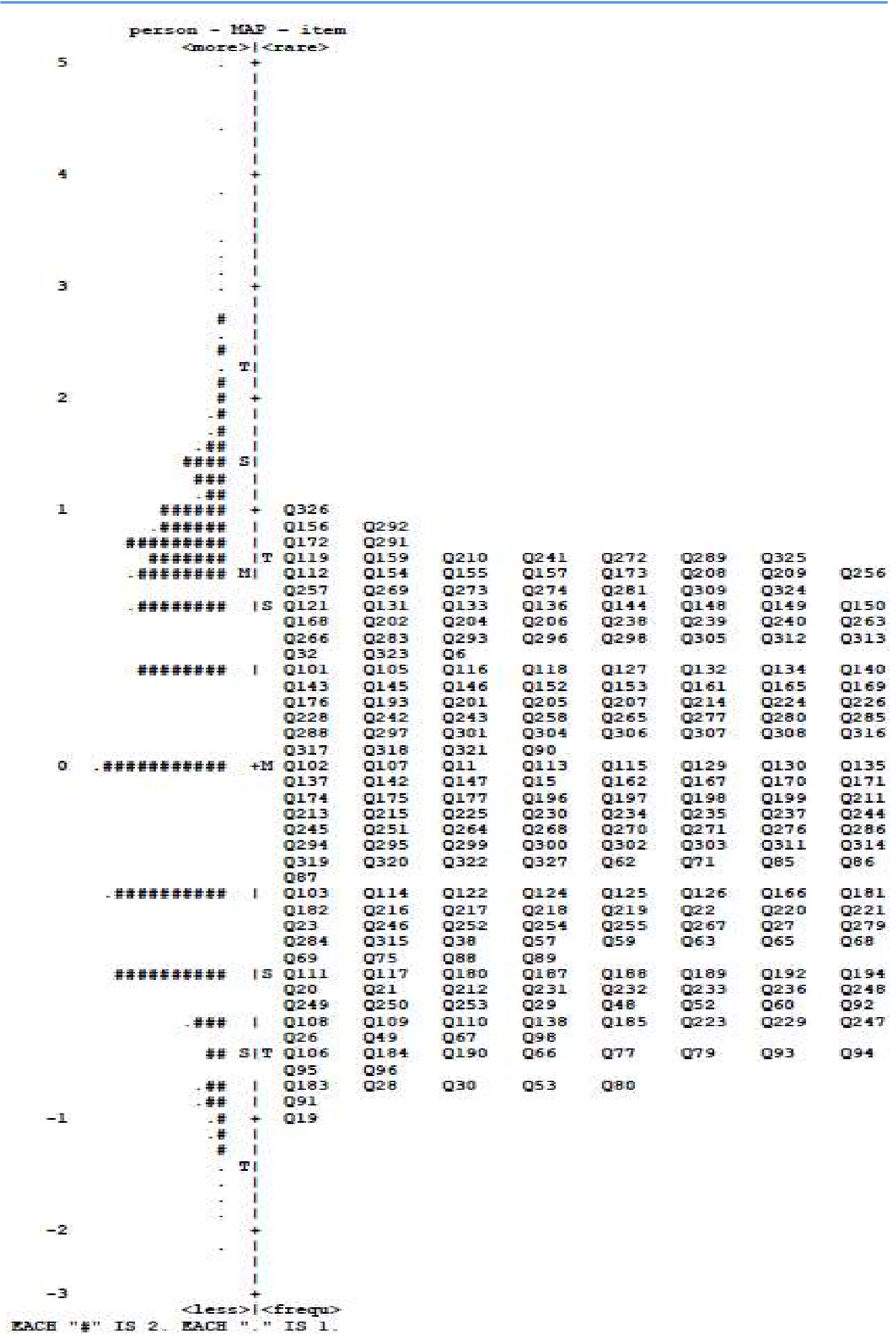

Fig.1. Item person map 
Fig. 1 shows the distribution of the item difficulties, which is matched against the distribution of student abilities along a logits scale on one continuum measurement from the easiest level to the most difficult level visually [16]. The map shows that item Q6 (I am able to relate to the seemingly contradictory views) is the most difficult item to endorse among the respondents. On the other hand, item Q14 (my everyday life has relations with nature) is the easiest item to endorse. The item difficulty value ranges from +0.95 to -1.04 logits. It meets the acceptable range of +3.00 to -3.00 logits and is deemed good and sufficient [41-43].

The gap between the distributions of items is also examined in order to test whether there are enough items to test all abilities of the individuals. The results showed that there are no gaps between the items. Further study is required in order to develop more MPCL items that are suitable to test respondents with high ability (ability to answer the items). The average standard error of measurement (SEM) is calculated as +0.09 logits, while the items' standard error ranges from +0.09 to +0.11 logits. Smaller values of both SEM and range of error show that the estimation of parameters has a certain degree of precision.

\subsection{Removal items}

Table 6 shows the list of the 83 dropped items in MPCL according to the MPCL dimensions. 52 items are removed because the Infit and Outfit MNSQ of these items are outside the acceptable range (0.7-1.30). Meanwhile, another 10 items are removed because of their point-measure correlation (PTMEA) are too low and have the negative values.

In addition, 21 items are removed because of these items exhibit differential item functioning (DIF) between gender. There are 83 items that have been removed due to the value exceeding the acceptable range such as the MNSQ (Infit and outfit) values, item polarity (PTMEA) and Differential Item Functioning DIF. This paper will not explain more about the DIF results. It only focuses on the item fit and PTMEA analysis. Therefore, the final version of MPCL only consists items that fulfill all Rasch measurement requirements which are 244 items. 
Table 6. Dropped items

\begin{tabular}{|c|c|c|c|c|c|c|}
\hline \multirow[t]{2}{*}{ Dimensions } & \multirow[t]{2}{*}{$\begin{array}{l}\text { Total } \\
\text { Items }\end{array}$} & \multicolumn{3}{|c|}{$\begin{array}{c}\text { Recommended Removal Items (Entry } \\
\text { Number) }\end{array}$} & \multirow[t]{2}{*}{$\begin{array}{c}\text { Items } \\
\text { Removed }\end{array}$} & \multirow[t]{2}{*}{$\begin{array}{l}\text { Items } \\
\text { Retained }\end{array}$} \\
\hline & & PTMEA & MNSQ & DIF & & \\
\hline Health & 30 & 3,4 & $\begin{array}{l}1,2,5,7,8,9 \\
10,12,13,14 \\
16,17,18,25\end{array}$ & 24 & 17 & 13 \\
\hline Finances & 30 & 47,55 & $\begin{array}{c}31,33,34,35, \\
36,37,39,40, \\
41,42,43,44, \\
45,46,50,51, \\
54,58\end{array}$ & 56 & 21 & 9 \\
\hline Recreation & 30 & $\begin{array}{l}72,73, \\
74,76, \\
82,83\end{array}$ & $\begin{array}{c}61,64,70,78 \\
81,84\end{array}$ & - & 12 & 18 \\
\hline Courtship & 27 & - & 100 & $97,99,104$ & 4 & 23 \\
\hline Social & 30 & - & 123 & $\begin{array}{l}120,128 \\
139,149\end{array}$ & 5 & 25 \\
\hline Personal & 30 & - & - & $\begin{array}{c}151,158, \\
160,163,164\end{array}$ & 5 & 25 \\
\hline Religion & 30 & - & $\begin{array}{l}178,186,191 \\
195,200,203\end{array}$ & 179 & 7 & 23 \\
\hline Family & 30 & - & 222 & 227 & 2 & 28 \\
\hline Career & 30 & - & - & $\begin{array}{l}259,260 \\
261,262\end{array}$ & 4 & 26 \\
\hline Education & 30 & - & $\begin{array}{l}275,278 \\
287,290\end{array}$ & 282 & 5 & 25 \\
\hline Learning & 30 & - & 310 & - & 1 & 29 \\
\hline & 327 & 10 & 52 & 21 & 83 & 244 \\
\hline
\end{tabular}




\section{CONCLUSION}

The study reports on examining the psychometric properties of items in MPCL and categorized the best fit items in relation to the challenges faced by the Malaysia polytechnic students. Based on a rigorous assessment of information from the Rasch model analysis, the results demonstrates some convincing evidence of high validity and reliability of the items for polytechnic students' context of applications. A total of 244 items of the MPCL was found to have good psychometric characteristics based on Rasch model, indicating its usability in the context of the polytechnics. Thus, it is recommended that educators and researchers can employed the modified version of the MPCL to identify the challenges among polytechnic students. In fact, it requires more studies, especially in terms of assessing respondent with higher ability to answer the items. Combination with qualitative approach is recommended, for example by interviewing the polytechnic students to explore more types of adversity encountered by the students. Special reporting on Differential Item Functioning (DIF) of MPCL items between groups is not covered in this study. DIF analysis is an important approach for the instrument validation and biasness when items that exhibit extreme levels of DIF are identified. Thus, educators and polytechnic management can use the information obtained from modified MPCL to identify students' adversity and overcome these challenges through the suitable programs. This study achieved its target to validate MPCL in the context of Malaysian polytechnic institutions in Malaysia.

\section{ACKNOWLEDGEMENTS}

We wish to express our gratitude to all the respondents and lecturers from the polytechnics involved in the study. Special appreciation goes to the Centre for Research and Development of Polytechnics (PPPP), Putrajaya for allowing us to conduct this study and for the Faculty of Education, UniversitiKebangsaan Malaysia (UKM) and School of Educational Studies, UniversitiSains Malaysia (USM) for the morale support. Thank you to all experts for their assistance with data analyses and initial comments on the manuscript.

\section{REFERENCES}

[1] Mooney R.L., Gordon L.V.Manual: The Mooney problem checklists. New York: 
Psychological Corporation, 1950

[2] Sidek M.N.Pengujian dan penilaian dalam kaunseling: Teori dan aplikasi.Selangor: Universiti Putra Malaysia, 2013

[3] Mohd E E M M, Ahmad Z K, Nurul H M R. Interpretation in correlating the Money Problem Check List dimensions using Rasch model.International Journal of Academic Research in Business and Social Sciences, 2016, 6(12):121-137

[4] Mohd E E M M, Ahmad Z K.Exploring the challenges faced by polytechnic students.AIP Conference Proceeding, 2015, 1643(101):101-107

[5] Mohd E E M M, Ahmad Z K. Mengenal pasti cabaran pelajar politeknik di Malaysia menerusi model Rasch.Journal of Quality Measurement and Analysis, 2014, 10(1):59-74

[6] Azizi Y, Yusof B, Jamaludin R, Shahrin H, Faizah I.Persepsi pelakuan agresif dan faktor yang mempengaruhi di lima buah sekolah di kawasan bandar Johor Bahru.SainsHumanika, 2010, 53 (1):75-94

[7] Azizi Y, Zainab P T, Zeliha M A, Gooh ML. The using of Mooney Checklist tool for problems faced by students in secondary.Australian Journal of Basic and Applied Sciences, 2014, 8(16):330-339

[8] Azeem C M. Educational problems of muslim adolescents: A study with special reference to Malabar region.Academic Research International, 2012, 2(1):545-556

[9] Hassan H, Nurfarahiyah M. Tinjauan kategori masalah dalam kalangan pelajar antarabangsa Universiti Teknologi Malaysia, Skudai, Johor Darul Takzim. Bachelor thesis,Johor: Universiti Teknologi Malaysia, 2010

[10] Hassan H, Vaskalista D N P. Tinjauan mengenai kategori masalah dalam kalangan pelajar tahun satu Fakulti Pendidikan, Universiti Teknologi Malaysia, Skudai, Johor Darul Takzim. Bachelor thesis,Johor: Universiti Teknologi Malaysia, 2008

[11] Alavi M, Syed M S S M.Categories of problems among international students in Universiti Teknologi Malaysia.Procedia-Social and Behavioral Sciences, 2011, 30:1581-1587 [12] Syed M S S M, Hairiza O. Kategori masalah pelajar tahun satu Kolej Tun Razak, $\begin{array}{lll}\text { Universiti Teknologi Malaysia, } & \text { Skudai }\end{array}$ Johor.International Journal of Education, Psychology and Counseling, 2011, 1:44-58

[13] Bond T.G., Fox C.M. Applying the Rasch Model: Fundamental measurement in the 
human sciences. Oxon: Routledge, 2015

[14]Linacre J M. What do infit and outfit, mean-square and standardized mean?Rasch Measurement Transactions, 2002, 16(2):878

[15] Fisher J W P. Rating scale instrument quality criteria.Rasch Measurement Transactions, 2007, 21(1):1095

[16] Bond T.G., Fox C.M. Applying the Rasch model: fundamental measurement in the human sciences. New Jersey: Routledge, 2007

[17] Siti R A, Shafiza M, Anita I, Sharida H, Abdul G A.Validity of UKM2 Intelligence Test using Rasch analysis. In 9th WSEAS International Conference on Education and Educational Technology, 2010, pp. 303-308

[18] Linacre J M. Investigating judge local independence. Rasch Measurement Transactions, 1997, 11(1):546-547

[19] Abu B. N., Bhasah A.B. Penaksiran dalam pendidikan dan sains sosial.Perak: Universiti Pendidikan Sultan Idris, 2008

[20] Linacre J.M. A user's guide to WINSTEPS: Rasch Model Computer Programs. Chicago: MESA Press, 2012

[21]Wu M., Adams R. Applying the Rasch model to psycho-social measurement: A practical approach. Melbourne: Educational Measurement Solutions, 2007

[22] Linacre J.M. WINSTEPS Computer Program Version 3.48.Chicago: MESA Press, 2003

[23] Wright B D, Masters G N. Number of person or item strata. Rasch Measurement Transactions, 2002, 16(3):888

[24] Azrilah A A, Muhammad S J, Omar A R, Mohd H A, Tuan S A. Construct validity: A Rasch measurement model approaches.Journal of Applied Science and Agriculture, 2014, $9(12): 7-12$

[25] Cohen L., Manion L., Morrison K. Research methods in education.New York: Routledge, 2011

[26]Creswell J.W. Educational research: Planning, conducting, and evaluating quantitative and qualitative research.Boston: Pearson Education, 2012

[27] Susila P. Masalah pelajar remaja daripada keluarga ibu tunggal di sebuah sekolah menengah di Puchong. Master thesis,Kuala Lumpur: Universiti Malaya, 2005 
[28] Wright B.D., Masters G.N. Rating scale analysis Rasch measurement. Chicago: MESA Press, 1982

[29] Kumar M., Salim A.T., Ramayah T. Business research methods.Selangor: Oxford University Press, 2013

[30] Conrad KM, Conrad KJ, Passetti L, Funk RR, Dennis ML. Validation of the GAIN self-help involvement scale using theRasch measurement model. Drug and Alcohol Dependence, 2014, 140:e37

[31] Eakman A M. Measurement characteristics of the engagement in meaningful activities survey in an age-diverse sample.American Journal of Occupational Therapy, 2012, 66(2):20-29

[32] Linacre J.M. A User's guide to WINSTEPS: Ministep Rasch Model Computer Programs. Chicago: MESA Press, 2007

[33] Embretson S.E., Reise S.P. Item response theory for psychologists. New Jersey: Lawrence Erlbaum Associates, 2000

[34] Hung M, Hon SD, Cheng C, Franklin JD, Aoki SK, Anderson MB, Kapron AL, Peters CL, Pelt CE. Psychometric evaluation of the lower extremity computerized adaptive test, the modified Harris hip score, and the hip outcome score. OrthopaedicJournal of Sports Medicine, 2014, 2(12):1-10

[35] Balsamo M, Giampaglia G, Saggino A. Building a new Rasch-based self-report inventory of depression.Neuropsychiatric Disease and Treatment, 2014, 10:153-65

[36] Azrilah A.A., Mohd S. M., Azami Z. Asas model pengukuran Rasch: Pembentukan skala dan struktur pengukuran.Selangor: Universiti Kebangsaan Malaysia Press, 2013

[37] Sekaran U., Bougie R. Research methods for business: A skill building approach. NewDelhi: John Wiley and Sons, 2011

[38] Hair J.F., Celsi M.W., Oritinau D.J., Bush R.P. Essentials of marketing research.New York: McGraw Hill, 2013

[39] Duncan P W, Bode R K, Lai S M, Perera S. Rasch analysis of a new stroke-specific outcome scale: The stroke impact scale.Archives of Physical Medicine and Rehabilitation, 2003, 84(7):950-963

[40] Green K E, Frantom C G. Survey development and validation with the Rasch Model. 
InInternational Conference on Questionnaire Development, Evaluation, and Testing,2002, pp. $1-42$

[41] Andrich D., Styles I. Final report on the psychometric analysis of the Early Development Instrument (EDI) using the Rasch Model: A technical paper commissioned for the development of the Australian Early Development Instrument (AEDI). Perth:Royal Children's Hospital, 2004

[42] Hill C, Koekemoer E. The development of the MACE work-family enrichment instrumen.SA Journal of Industrial Psychology, 2013, 39(2):1-16

[43] Linacre J M. Sample size and item calibration (or person measure) stability.Rasch Measurement Transactions, 1994, 7(4):328

\section{How to cite this article:}

M. E. E. MohdMatore, A. Z. Khairani, N. AbdRazak, M. Mohamad,Improving the psychometric properties of the mooney problem checklist by using rasch measurement model, J. Fundam. Appl. Sci., 2017, 9(6S), 408-428. 